Katarzyna Szuper

\title{
Globalization of modern economies
}

\author{
Globalizacja wspótczesnych gospodarek
}

\section{Introduction}

Globalization is a well-known concept which affects all areas of life. Globalization processes occur naturally. They are changing the conditions of the world around us. The effect of these processes is the penetration of economic, political, cultural and social life spheres of life This is determined by technological progress and the development of computerization.

Globalization, which is gaining momentum, has a significant impact on the economy. In economic terms, globalization is considered the highest degree of internationalization of economic activity. Entities operating on the global market make decisions from a global, rather than local point of view. Globalization is a multi-threaded term, which describes complex processes that currently occur in the economy.

The purpose of this work is to show how important globalization is for the contemporary world economy, as well as how globalization processes affect the structure and direction of international trade. The study is based on an analysis of literature.

\section{The concept of globalization}

Globalization is a popular concept. It is on everyone's lips. It is an unavoidable fate of the world, and an irreversible process that affects everyone in the same 
way (Bauman, 2000). At present it is progressing faster and affecting almost all spheres of life. To understand the impact and dimension of globalization better, we should first define it.

In the mid-1980s, Roland Robertson used the term globalization for the first time to describe cultural and religious phenomena. According to the English sociologist "Globalization is a concept which refers to both 'shrinking of the world' and increasing the degree of understanding of the world as a whole. Both of these factors strengthen global independence and comprehension of the world as a whole in the $20^{\text {th }}$ century" (Czaja, 2001, p. 65).

Flejterski and Wahl (2003) have developed another proposal. They said that "globalization is still qualitatively a new socio-economic structure which dominates the modern world. It crystallized at the end of the $20^{\text {th }}$ century as a result of blending similar processes that are simultaneously taking place across the globe" (p. 16).

To quote Czaja (2001) "globalization as a very general and capacious term means the dissemination, duplication and unification of patterns of conduct, acceptance of popular scientific attitudes by the media, the penetration of cultural elements, the mixing of these elements, as well as the speed with which these processes occur thanks to the achievements of technology (information technology revolution)" (p. 67).

The Council of Europe describes this issue as follows - "the ever closer economic integration of all the countries of the world resulting from the liberalization and consequent increase in both the volume and the variety of international trade in goods and services, the falling cost of transport, the growing intensity of the international penetration of capital, the immense growth in the global labour force, and the accelerated worldwide diffusion of technology, particularly communications" (European Union, 2017, p. 8).

The simplest definition of globalization of the economy is to understand it as "the free movement of goods, services, labor, capital and knowledge between countries" (Oramah \& Dzene, 2019). While following the anti-globalist thinking, "Globalization is a process of leveling down, bringing employees worldwide to one, lowest denominator" (Horodyski, 2002, p. 87). The definitions presented above illustrate different points of view but refer to the same process.

The concept of globalization has been evolving for over 150 years. This time is usually divided into periods in different ways. Heshmati (2006) in his paper proposed the following division: the first wave of globalization is the years 18701913, the years 1913-1950 is a period of retreat from globalization, the golden age of globalization falls in the years 1950-1973, and since 1973 there has been 
a second wave of globalization. Many scientists are asking why it is only now that so intense interest in globalization has appeared, looking at over 150 years of its history (Hirst \& Thompson, 2019). The EC analysis partially explains this issue. Despite the fact that recently the level of liberalism in capital turnover which occurred at the beginning of the 20th century has been gained, foreign capital in global GDP has four times more share than at the end of the first wave of globalization. Moreover, the share of international trade in the GDP of many countries is higher. Additionally, it has been noticed that in recent years there has been a strong increase in the share of these forces (OECD, 2020).

Speaking of globalization processes, we can distinguish four main dimensions: technical, economic, political and socio-cultural (Pehlivan, Efeoglu \& Han, 2019).

According to Giddens (2012), the unification of markets and goods traded on them is the main determinant of economic globalization. The effect of this is the removal of barriers in international trade, which means that companies from different countries can compete effectively on foreign markets. However, local companies are not at the center of globalization of the economy, but rather transnational corporations that have their headquarters in wealthy countries are. A common phenomenon is the greater importance of these corporations than of some countries in global markets . A feature of this dimension of globalization is the transfer of financial crises occurring in one part of the globe to the whole world.

In his book, Piotr Sztompka (2005) indicates the determinants of cultural globalization, such as frequent changes of location, tourism, a common language, and, above all, the commercialization of cultural products and the development of mass communication. The author also notes the processes of mcdonaldization of society, consumerism and Americanization. In addition, globalization has an impact on perception of identity which is changing by opening societies to new experiences and taking over elements of another culture (Burdzik, 2013). Four scenarios for the fate of global cultural connections have been developed (Hannerz, 1987):

- "global hegemonization" scenario - the dominance of Western culture at the expense of local cultures,

- "cultural saturation" scenario - a slow disappearance of local traditions over several generations,

- "cultural deformation" scenario - mixing Western and local culture, adopting lower-level values and adapting Western culture to local standards,

- the scenario of "maturing cultural amalgamation" - an equal dialogue and exchange between cultures leading to cultural enrichment. 
The World Bank, International Monetary Fund or World Trade Organization are some of the international organizations that have emerged as a result of globalization of politics. Thanks to their competences, they control the global economy, limiting the independence of states. The unions of states, i.e. the European Union, the African Union and the Union of South American Nations are also often mentioned here (Giddens, 2012). The globalization process is no longer just a social tendency, but it is becoming an indicator for a better world.

\section{Economic globalization factors}

The most important factors of economic globalization depend on the author who presents them. For example Sznajder (1995) distinguishes:

- factors related to buyers - demand for related products calculated on an international scale, development of global markets,

- factors related to trade and distribution - similar structure of trade and marketing strategies,

- factors related to promotion - development of mass media and tourism,

- factors related to innovation - shortening the life cycle of products,

- factors related to market competition - using economies of scale in distribution and promotion, the ability to respond to market needs.

Buzzel, Quelch and Bartlett (1995) present a different division. According to them, the most important stimuli of economic globalization include: the growing importance of the effect of economies of scale, unifying the needs in the world, disappearing barriers in international trade, eliminating disproportions between living standards of people from different countries of the world and the emergence of a global client.

However, the most transparent division of economic globalization factors separates them into two groups (Yip, 2004):

- external factors - include political, legal factors and market factors of the external environment determining the conditions for the development of international trade entities,

- internal factors - include cost and competitive factors of the internal environment determining the globalization potential of the entity.

Political and legal factors have contributed to the economic integration of huge areas and the creation of economic blocks. States form unions in which the unification of law, society, fiscal and monetary policy are progressing, and, above all, customs barriers and various legal restrictions that hinder the development 
of international trade are lifted. The intensification of global trade depends on the openness of borders regulated by international agreements and on the costs (Koźmiński, 1999). The commercial policy of governments shapes tax law, affects trade costs through the application of tariffs and quantitative restrictions and influences the choice of organizational and legal forms of entities conducting business activity. In addition, government policy can facilitate the introduction of globally comparable quality and technical standards and harmonize certain marketing regulations (Yip, 2004). A favorable trade policy increases the free movement of capital, intensifies competition, reduces the number of weak entities by changing the structure of the market and enables the entity to use its own competitive potential in global markets. As a result of globalization, the process of capital raising takes place, networks of commercial and investment-production connections appear, and thus the interdependence of global entities increases. Undoubtedly, the independence of states decreases and the importance of international corporations increases with the development of globalization processes. This is often results in global companies taking over some of the state's functions, i.e. covering the costs of scientific research, creating jobs, co-financing employee insurance, ensuring the well-being of the country and its technological independence. The state is interested in cooperation with transnational corporations and supports them through skillful control of public markets, trade measures, tax breaks, participation in public international programs and support for research programs. Thus, there is a mass flow of public funds to the private sector, in particular to global companies, which allows them to maintain and often also increase their competitive position on the international market. The effect of these changes is the growing gap between political and economic power (Brózda, 2003).

At the same time, market factors increase the economic differences between countries. On the one hand, they affect global business entities to even the odds. The progressing process of unifying the lifestyles of residents around the world has increased the role and importance of electronic media. The development of information transfer technology has also become the cause of the emergence of global advertising, which is conducive to global demand (so-called "Californization of needs"; Koźmiński, 1999). Uniform consumer needs are also favored by the increasing dynamics of growth and equalization of average levels of GDP and GDP per capita, which results in the increasing purchasing power of humanity. From the point of view of global enterprises, unification of global demand is conducive to the development of these companies, enables them to enter various types of foreign markets with a product known all over the world, and above all, allows them to improve international competitive position in the market. 
The universalization of consumption patterns has led to the creation of global products, brands, promotions and global marketing. Global trade companies are trying to standardize their marketing strategy in order to be able to introduce their products on the markets of foreign countries with as little modification as possible. Therefore, transferable marketing is an additional dimension of global competition, which forces corporations to adapt their marketing program to the requirements of a given country (Koźmiński, 1999). An important factor in economic globalization is scientific and technical progress. The innovativeness associated with it affects economic growth, stimulates the market expansion of enterprises, changes the environment of enterprises through progress in the field of connectivity, production, transport (primarily reducing time and space barriers, reducing transport costs by facilitating the movement of resources owned by the company) (Brózda, 2003). The increasingly important networks of the flow of people, goods, information and production efficiency determine the globalization process. Progress in the above areas affects the development of innovation, which increases the efficiency of methods used by enterprises. Technical progress forces global companies to cooperate with specialized scientific and research units located all over the world. The network of international connections between units conducting joint research is growing, the technology life cycle is shortened and the process of introducing new solutions to individual countries is accelerating (Zorska, 1998). The emergence of global clients is also a stimulus for globalization. This type of customers make centralized purchases for such use. Often "global clients" can be understood as all kinds of influential groups, usually government agencies and industrial producers. The existence of such clients requires global market participation, global product development and global marketing (Yip, 2004). The existence of lead countries also determines the dynamics and strength of globalization. These countries are characterized by high innovation and implementation of innovative processes for production. A characteristic feature is the mass implementation of new technologies and the presence of major global companies on their markets. The efforts of global companies to cope with competition mean that they want to be present in the markets of the most developed countries. Therefore, the leading countries are the target of market expansion, which increases the availability of products in their markets and the presence of competition. Achieving a strong competitive position in these markets has strategic importance for the development and future of global companies (Yip, 2004).

Cost factors of economic globalization have a significant impact on the activities of global enterprises (global location of the business, product or participation 
in the global market). They are a source of global competitive benefits. The use of economies of scale demonstrates the desire to minimize production costs. Economies of scale can be achieved by combining the same company functions undertaken in different countries, as well as by moving parts of the production cycle abroad, i.e. through foreign direct investment (Rymarczyk, 1996). Further cost factors include the range effect. It involves the creation of products and the combined production of several products, because the total cost of their manufacture is lower than separate production. Thanks to this, the company generates savings (Pierścionek, 1998). The benefits of experience should not be overlooked. Labor productivity and production increase as a result of acquisition of experience and specialization, improvement of the production process, change in production technology and organization of work. The scope of benefits resulting from experience increases the efficiency of entering global markets (Pierścionek, 1998). Logistic improvement is another of these factors. It covers activities aimed at the security of shipping and shortening their transport time, as well as reducing its costs. Due to the ease of product movement, competition in the area of production capacity increases (Yip, 2004). A global enterprise often benefits from the synergy effect. There are connections between specific sources of competitive advantage that enhance the effects of their occurrence. Relatively comparative advantage is achieved by newly industrialized countries with high production capacity and low labor costs. These benefits mainly result from global market imperfections. When production in a given country is the most profitable, global companies locate their production there and export products to other parts of the world. Cost differentiation of countries is therefore the main criterion for the location of economic activity. The group of these criteria includes: costs of raw materials, land, energy, taxes, expenses for environmental protection, cost of obtaining a loan. This diversity is a strong element of economic globalization, because the higher the cost disproportion, the greater the relocation of production (Brózda, 2003). The occurrence of such elements as economies of scale, diversity of goods on the market and the existence of monopolistic competition have become the basis for Paul Krugman's development of a new theory of international trade. It assumes that consumers will want to purchase a larger amount of the same good as its market availability increases, assuming its price stability, and increasing labor productivity is assumed for producers. Krugman notes that by creating a larger market, you can capitalize on increasing productivity, which will increase real wages and increase accessibility for consumers of the same kind of goods. The assumptions adopted by Krugman translate into economic geography, which deals with the study of the location of production, distribution of capital and 
labor in countries and regions. New economic geography is a theory that allows us to understand the location of enterprises. This is due to the trade-off between using economies of scale and saving on transport costs (Romiszewska, 2010). The emergence of new technologies shortens the product's life cycle and causes increasing costs of its production. It becomes necessary to incur high financial expenses for research and development. Companies wanting to spread these costs on the largest possible number of markets are deciding to globalize their business. This stimulates the establishment of international cooperation in the field of research and development, but also increases economic interdependence between countries (Sznajder, 1995). An important feature possessed by global entities is the mobility of production. Specialized employees, knowledge and experience can effectively serve subsidiaries based around the world, by intensifying the effect of experience (Brózda, 2003).

Economic globalization factors belonging to the group of competitive factors are undeniably related to all the aforementioned elements. The constantly growing level of world trade turnover forces companies wishing to maintain their position to expand into various foreign markets (Latoszek \& Kłos, 2015). It is a direct cause of the occurrence of an increasing number of countries - competitors on global markets. The increasing volume of foreign direct investment increases the share of foreign entities in the ownership structure of domestic enterprises, thereby increasing the economic interdependence of countries, which is another competitive factor. Growing cooperation of entities on global markets favors the emergence of global networks of relationships between global market participants and building strategic alliances (Brózda, 2003).

External and internal conditions stimulate the process of globalization. A clear division of these factors is impossible because they occur in cause and effect relationships. However, an attempt to recognize and classify them is necessary when implementing global expansion of entities.

\section{Benefits and threats of globalization for modern economies}

Globalization is neither good nor bad in itself, but the use of processes under its influence can bring both benefits and threats. As noted by Sztompka (2005), globalization has contributed to the increase of economic, financial, political, strategic and cultural dependence and interdependence between all countries of the world. 
From the point of view of economics and finance, the globalization process brings benefits in the form of: economic growth, increase in the quality of goods and services, increase in global demand, improvement of the quality of life of the population, creation of new jobs, increase in trade exchange, reduction of production and communication costs, transfer of new technologies and knowledge, integration of financial markets and effective capital allocation. On the other hand, the dangers of globalization in this regard are primarily: uncontrolled privatization of the public sector, increasing dominance of some countries, growing distance between individual world economies, increasing unemployment (Cernat \& Mustilli, 2018), spread of all kinds of crises, rise in aggressive competition, destruction of domestic industry by accepting foreign capital.

From the perspective of the political zone, the pros of globalization are: the disappearance of barriers in international cooperation, promotion of human rights, regional integration of countries in the world, unification and democratization of the world system, institutionalization and formalization of international relations. Disadvantages due to globalization include limiting the sovereignty of states, reducing the role of national governments and the importance of international organizations, a decrease in the scale of democratization at international level, loss of trust in international institutions (Woodward, 2019).

The socio-cultural zone is equally subject to globalization processes. The benefits it brings include: easier access to goods, services, new technologies, knowledge, cultural achievements, openness to cultural diversity, and the formation of a "global people" (Yudice, 2018). The expansion of the areas of poverty, the globalization of criminal organizations, the blurring of cultural differences and national distinctions, the insecurity of one's own identity are the most important negative phenomena that globalization brings in the socio-cultural zone (Ślusarczyk, 2010).

Analyzing the benefits and threats of globalization, one cannot talk about all economic entities. Depending on the level of economic development or the level of qualifications, entities feel the impact of globalization differently. The greatest benefits from this process are felt by: highly developed countries and Asian countries, international corporations, new technology sectors, mobile people, qualified workers, individuals willing to take risks (Weiss, Sachs \& Weinelt, 2018). The losses will be suffered by: less developed countries, small and medium-sized local enterprises, traditional sectors, workers and people dependent on social protection (Oziewicz, 2006).

Interpretation of the pros and cons that result from globalization is not clear. Although it has been pointed out that underdeveloped countries are losing to 
globalization, it cannot be said that they have not benefited from it at all. Examples include the increase in foreign investment in these countries, a number of facilities in world trade, or even growing GDP. Globalization has brought a number of benefits, mainly creating new trade opportunities, increasing access to markets and technologies, improving the level of health in the world, the emergence of a global society that actively fights for democracy and social justice. The problem of the ambiguity of the impact of globalization on the modern world is not in itself but in the way it is interpreted (Stiglitz, 2012).

\section{Globalization after 2008}

Recent years have brought changes in the global world. Many scientists and journalists have foretold the end of globalization. However, no strong arguments for a shift away from globalization that took place in the 1930s-1940s can be found. As Harari (2018) points out, the globalization of science cannot be undone and the cost of reversing globalization would be an insurmountable barrier. Despite the cooling and slowing down of internationalization of economies after 2008, we can consider this period as a transition to a new stage, and not as a breakup of global world structures. It is not possible to repeat the scenario of the great crisis of the last century because of the changes that have taken place in the economy in recent years (Manzi, 2019). We need to make adjustments to globalization processes that would eliminate deviations rather than the entire output of previous stages. The weakening of globalization forces is influenced more by national and international policies than low economic growth. More and more western countries are pursuing state and pro-market policies. On the other hand, China and emerging countries which are playing an increasingly important role in the international arena support globalization because it has stimulated their national economies. Therefore, two models of globalization can be expected in the near future: western and eastern. They will interact, but it remains to be seen whether full convergence is possible (Madej, 2020).

The main change after 2008 was the replacement of G7 by G20. The rise of emerging countries and their stronger impact on the global economy have caused difficulties in reaching agreement and consensus. Structural changes lead to the decentralization of financial and commercial institutions and to the undermining of current cooperation principles. Some changes are already taking place in the IMF, the World Bank and global financial architecture. The WTO also needs reform. An obvious step will be to increase the role of multilateral 
agreements, change the provisions on special and differential treatment, extend issues that go beyond traditional trade, harmonize the legal system. There is a need to create clear mechanisms that will represent the interests of all entities in the global market. (Zagashvili, 2019). Another noticeable feature is the weakening of the global gross product growth rate and a decrease in the global trade growth rate (OECD, 2020). Technology and its global commercialization are still very important, while technology is changing the shape of the operational model of global production. The modernization of production technologies can speed up production and increase its productivity. This means that international corporations will have to reconsider relocating their production factories to more developed countries, because the benefits of using modern technologies can far outweigh the benefits of cheap labor. This will result in faster delivery and reduced transport costs. The share of global services, especially digital services, is constantly growing. Thanks to digital platforms, it has become possible for small and medium-sized enterprises to effectively compete with giant companies on the global market. (Śliwiński, 2018). Public sector action to lift trade barriers and openness to innovation such as electronic payments and improved logistics will be necessary (Brennan, 2016). Currently, work on artificial intelligence is in progress It can help solve the problems people face, but at the same time may contribute to deepening inequalities in the world. The political and economic balance of power will have a significant impact on the effects of the use of artificial intelligence. The impact of digital technologies on the global market will be huge, but it will not change the old system completely. A large internal market will regain importance in developing countries. In the case of developed countries, growth will be driven by technologies and innovations (Śliwiński, 2018).

It is not known how long this transition phase will last. Four scenarios are envisaged for the future stage of globalization. In the first scenario, it is assumed that the nation state will be able to interact with the global market, maintaining sovereignty. The second scenario is similar to the first one but with global market dominance. The third solution provides for the cooperation of equal partners - the state and the market. The fourth scenario predicts the emergence of the world based on artificial intelligence. It will be an ideal order, because it will be created without the unreliability of human reason (Harari, 2018). However, it is difficult to determine which model of the global world will dominate in the next phase of globalization. The biggest difficulty is that no one knows where the golden mean is. 


\section{Summary}

Globalization is an irreversible, long-lasting and dynamic phenomenon. It has been a popular and well-known concept all over the world for many years. Globalization is most often understood as reducing the world and increasing its comprehension as a whole. Globalization affects all spheres of human activity. Its main dimensions are technical, economic, political and socio-cultural dimensions. Its influence is undeniable and visible in transformations taking place all over the world. Many factors that stimulate the globalization process occur in causal connections. Therefore, a clear division is not possible. Globalization brings both, benefits and threats. The direction of its development and results depends on the impact on this process by individual entities. Those that can flexibly adapt to changes and take advantage of new conditions in their own development will benefit the most from globalization. Unfortunately, often when some benefit, others suffer losses. Increased social inequalities due to globalization can contribute to dissatisfaction among many people. That is why it is so important to shape globalization processes in such a way that they are beneficial to as many entities of the world economy as possible. Many scientists and journalists foretell the end of globalization. However, the changes we have seen in recent years may point to the transition to a new stage of globalization. The current situation is strongly influenced by national policy, a change in the balance of power on the global market, technological development and work on artificial intelligence. The considerations taken at work do not exhaust the enormity of issues related to globalization. They review definitions and factors and stress that globalization has both positive and negative effects.

\section{References}

Bauman, Z. (2000). Globalizacja. I co z tego dla ludzi wynika. Warszawa: PIW.

Brennan, T. (2016). Ma's Call for Inclusive Trade Heard by G20, WTO. Retrieved from https:// www.alizila.com/mas-call-for-inclusive-trade-heard-by-g20-wto/ (27.05.2020).

Brózda, J. (2003). Czynniki globalizacji gospodarczej. In T. Bernat (Ed.), Problemy globalizacji gospodarki. Szczecin: PWE.

Burdzik, T. (2013). Między indywidualizmem a zbiorowościa - globalizacja a tożsamość. Horyzonty Wychowania, 12(24), 59-73.

Buzzel, R. D., Quelch, J. A., \& Bartlett, Ch. A. (1995). Global Marketing Management. Cases and readings ( $3^{\text {th }}$ ed.). Reading: Addison-Wesley.

Cernat, L., \& Mustilli, F. (2018). Trade and Labour Market Adjustments: What Role for the European Globalisation Adjustment Fund? Intereconomics, 53(2), 79-86. 
Czaja, I. (2001). Globalizacja, globalizm, przedsiębiorczość - szanse i zagrożenia. In J. Klich (Ed.), Globalizacja (pp. 64-82). Kraków: Wydawnictwo Profesjonalnej Szkoły Biznesu.

European Union (2017). Globalisation pattern In UE trade and investment. 2017 edition. Luxembourg: Publications Office of the European Union.

Flejterski, S., \& Wahl, P. T. (2003). Ekonomia globalna. Synteza. Warszawa: Difin.

Giddens, A. (2012). Socjologia (tłum. O. Siara, A. Szulżycka, P. Tomanek). Warszawa: PWN. Hannerz, U. (1987). The World in Creolization. Africa, 57(4), 546-559.

Harari, Y. N. (2018). Homo deus. Krótka historia jutra (tłum. M. Romanek). Warszawa: Wydawnictwo Literackie.

Heshmati, A. (2006). Measurement of a Multidimensional Index of Globalization. Global Economy Journal, 6(2), 1-30.

Hirst, P., \& Thompson, G. (2019). The future of globalisation. In J. Michie (Ed.), The Handbook of Globalisation $\left(3^{\text {th }}\right.$ ed., pp. 16-31). Cheltenham: Edward Elgar Publishing.

Horodyski, M. (2002). Globalizacja, antyglobaliści i głód miodu. Państwo i Społeczeństwo, 2(2), 75-90.

Koźmiński, A. K. (1999). Zarządzanie międzynarodowe. Konkurencja w klasie światowej. Warszawa: PWE.

Latoszek, E., \& Kłos, A. (2015). The European Union Competition Policy in the Context of Globalisation of the World Economy. In E. Latoszek, M. Proczek, A. Kłos, M. Pachocka, E. Osuch-Rak \& D.W. Elipsa (Eds.), Facing the Challenges in the European Union. Re-thinking EU Education and Research for Smart and Inclusive Growth (EuInteg) (pp. 363-373). Warszawa: PESCA.

Madej, Z. (2020). Kolejna korekta czy koniec globalizacji? Ekonomista, 1, 7-35.

Manzi, R. H. D. (2019). Economic globalization in the global post-crisis of 2008: limits and deadlocks. Brazilian Journal of Political Economy, 39(156), 470-484.

OECD (2020), Trade in goods and services (indicator). Retrieved from https://data.oecd. org/trade/trade-in-goods-and-services.htm (17.05.2020).

Oramah, B., \& Dzene, R. (2019). Globalisation and the Recent Trade Wars: Linkages and Lessons, Global Policy, 10(3), 401-404.

Oziewicz, E. (2006). Przemiany we współczesnej gospodarce światowej. Warszawa: PWE. Pierścionek, Z. (1998). Strategia rozwoju firmy. Warszawa: PWN.

Pehlivan, C., Efeoglu, R., \& Han, A. (2019). Factors affecting globalization: an application on fragile five countries. Turkish Studies, Social Scinces, 14(6), 3401-3413.

Romiszewska, E. (2010). Nowa teoria handlu międzynarodowego i geografii gospodarczej Paula Krugmana - laureata Nagrody Nobla w 2008 roku. Zeszyty Naukowe Państwowej Wyższej Szkoły Zawodowej w Płocku. Nauki Ekonomiczne, 12, 105-120. Rybiński, K. (2007). Globalizacja w trzech odsłonach. Warszawa: Diffin. 
Rymarczyk, J. (1996). Internacjonalizacja przedsiębiorstwa, Warszawa: PWE. Stiglitz, J. E. (2012). Globalizacja (tłum. H. Simbierowicz). Warszawa: PWN. Sznajder, A. (1995). Strategie marketingowe na rynku międzynarodowym. Warszawa: PWN. Sztompka, P. (2005). Socjologia zmian społecznych. Kraków: Znak. Śliwiński, R. (2018). Czynniki zmieniające proces globalizacji, Studia Ekonomiczne. Zeszyty Naukowe Uniwersytetu Ekonomicznego w Katowicach, 372, 7-19.

Ślusarczyk, B. (2010). Teoretyczno-praktyczne aspekty globalizacji gospodarczej. Częstochowa: Wydział Zarządzania Politechniki Częstochowskiej.

Weiss, J., Sachs, A., \& Weinelt, H. (2018). 2018 Globalization Report. Who benefits most from globalization? Gütersloh: Bertelsmann Stiftung.

Woodward, R. (2019). Governance in a globalised world. In J. Michie (Ed.), The Handbook of Globalisation ( $3^{\text {th }}$ ed., pp. 324-333). Cheltenham: Edward Elgar Publishing.

Yip, G. S. (2004). Strategia Globalna. Tłum. K. Bolesta-Kukułka. Warszawa: PWE.

Yudice, G. (2018). The globalization of culture and the new civili society. In S. E. Alvarez, E. Dagnino, \& A. Escobar (Eds.), Cultures of politics, politics of cultures: Re-visioning Latin American Social Movements. New York: Routledge.

Zagashvili, V. (2019). WTO Crisis as Manifestation of Globalization Crisis, Mirovaya ekonomika i mezhdunarodnye otnosheniya, 6(63), 5-12.

Zorska, A. (1998). Ku globalizacji? Przemiany w korporacjach transnarodowych $i w$ gospodarce światowej. Warszawa: PWN.

\begin{abstract}
The purpose of the article was to show the importance of globalization for modern economies. Presenting the concept of globalization and its essence makes an assumption that it affects all aspects of human activity legitimate. Globalization is a multi-threaded term consisting of complex processes. The article presents various definitions of this concept and division of economic globalization factors. However, their clear division is not possible, because they occur in cause and effect relationships. The effects of globalization felt by individual entities depend on the degree of economic development or qualifications. The problem of the ambiguity of the impact of globalization on the modern world lies not in globalization itself but in the way it is interpreted. The article also presents globalization after 2008 and possible scenarios for the future stage of globalization.
\end{abstract}

KEYwords: globalization, globalization factors, modern economies.

\title{
Streszczenie
}

Celem artykuły było ukazanie znaczenia globalizacji dla współczesnych gospodarek. Przedstawienie pojęcia globalizacji i zaprezentowanie jej istoty pozwoliło zauważyć, że oddziałuje ona na wszystkie aspekty działalności człowieka. Globalizacja jest terminem 
wielowątkowym, składającym się ze złożonych procesów. W artykule przedstawiono różne definicje tego pojęcia. Zaprezentowano podział czynników globalizacji gospodarczej. Jednak ich wyraźny podział nie jest możliwy, gdyż występują one w związkach przyczynowo-skutkowych. Skutki globalizacji, odczuwane przez poszczególne podmioty, zależą od stopnia rozwoju gospodarczego lub posiadanych kwalifikacji. Problem dwuznaczności wpływu globalizacji na współczesny świat nie leży w niej samej, ale w sposobie jej interpretowania. W artykule zaprezentowano także globalizację po 2008 roku i możliwe scenariusze dotyczące przyszłego etapu globalizacji.

SŁowA KLUCzowE: globalizacja, czynniki globalizacji, współczesne gospodarki.

\section{Nota o autorze}

Katarzyna Szuper - mgr; doktorantka na Wydziale Ekonomicznym Uniwersytetu Marii Curie-Skłodowskiej w Lublinie; katarzyna.szuper@live.umcs.edu.pl; zainteresowania naukowe: finanse przedsiębiorstw, innowacyjność, globalizacja, międzynarodowe stosunki ekonomiczne; ORCID: 0000-0003-4191-336X. 